Check for updates

Cite this: RSC Adv., 2017, 7, 25504

\title{
Synthesis of $\mathrm{g}-\mathrm{C}_{3} \mathrm{~N}_{4}$ nanosheet modified $\mathrm{SnO}_{2}$ composites with improved performance for ethanol gas sensing
}

\author{
Jianliang Cao, (D) ${ }^{a}$ Cong Qin, ${ }^{a}$ Yan Wang, (D) *b Huoli Zhang, ${ }^{a}$ Bo Zhang, ${ }^{c}$ \\ Yuxiao Gong, ${ }^{a}$ Xiaodong Wang, ${ }^{c}$ Guang Sun, ${ }^{c}$ Hari Bala ${ }^{c}$ and Zhanying Zhang*c
}

\begin{abstract}
The composites of $\mathrm{SnO}_{2}$ have attracted much interest in the last few years due to their excellent sensing properties. A series of composites were prepared with two-dimensional (2D) g- $\mathrm{C}_{3} \mathrm{~N}_{4}$ nanosheet modified $\mathrm{SnO}_{2}$ by a simple hydrothermal method in this work. The as-prepared composites were characterized by the techniques of powder X-ray diffraction (XRD), thermogravimetric analysis (TG), scanning electron microscopy (SEM), transmission electron microscopy (TEM), energy dispersive $X$-ray spectroscopy (EDS), $\mathrm{N}_{2}$ sorption and $X$-ray photoelectron spectroscopy (XPS). The gas sensing measurement results indicated that the sensor based on $\mathrm{g}-\mathrm{C}_{3} \mathrm{~N}_{4} / \mathrm{SnO}_{2}$ composite showed high sensitivity and excellent selectivity for detection of ethanol vapor. At $500 \mathrm{ppm}$ of ethanol vapor, the response value $\left(R_{\mathrm{a}} / R_{\mathrm{g}}\right)$ of $5 \mathrm{wt} \% 2 \mathrm{D} \mathrm{g}$ $\mathrm{C}_{3} \mathrm{~N}_{4}$ modified $\mathrm{SnO}_{2}$ was 240 at $300{ }^{\circ} \mathrm{C}$. Therefore, the $\mathrm{g}-\mathrm{C}_{3} \mathrm{~N}_{4} / \mathrm{SnO}_{2}$ composites have a great potential ethanol gas sensing application.
\end{abstract}

Received 16th February 2017

Accepted 8th May 2017

DOI: 10.1039/c7ra01901g

rsc.li/rsc-advances

Furthermore, Zhang et al. ${ }^{28}$ investigated the $\mathrm{MnO}_{2} / \mathrm{g}-\mathrm{C}_{3} \mathrm{~N}_{4}$ sandwich nanocomposite which showed satisfying performance on turn-on fluorescence response. Recently, Zeng et al. ${ }^{29}$ prepared the $\alpha-\mathrm{Fe}_{2} \mathrm{O}_{3} / g-\mathrm{C}_{3} \mathrm{~N}_{4}$ composites which displayed distinguished cataluminescence properties in the process of detecting $\mathrm{H}_{2} \mathrm{~S}$ gas. These reports indicate that g- $\mathrm{C}_{3} \mathrm{~N}_{4}$ had the ability to improve electrical characteristics of metal oxides.

In this work, the $2 \mathrm{D} g-\mathrm{C}_{3} \mathrm{~N}_{4}$ nanosheets $\left(2 \mathrm{D} \mathrm{g}-\mathrm{C}_{3} \mathrm{~N}_{4}\right)$ were synthesized according to the previous literature report. ${ }^{30}$ The $2 \mathrm{D}$ $\mathrm{g}-\mathrm{C}_{3} \mathrm{~N}_{4}$ modified $\mathrm{SnO}_{2}$ composites were prepared with $2 \mathrm{D} \mathrm{g}$ $\mathrm{C}_{3} \mathrm{~N}_{4}, \mathrm{SnCl}_{4} \cdot 5 \mathrm{H}_{2} \mathrm{O}$ and $\mathrm{NH}_{3} \cdot \mathrm{H}_{2} \mathrm{O}$ as the precursor materials by the hydrothermal method. The as-prepared samples were characterized by XRD, TG, SEM, TEM, $\mathrm{N}_{2}$ sorption and XPS. The sensing properties of the $\mathrm{g}-\mathrm{C}_{3} \mathrm{~N}_{4} / \mathrm{SnO}_{2}$ composites to ethanol gas were investigated in detail. The results showed that the 2D g- $\mathrm{C}_{3} \mathrm{~N}_{4}$ can effectively improved sensing properties of $\mathrm{SnO}_{2}$ to ethanol gas. The composite of $5 \mathrm{wt} \% 2 \mathrm{D} \mathrm{g}-\mathrm{C}_{3} \mathrm{~N}_{4}$ modified $\mathrm{SnO}_{2}$ has the optimum performance for detection of ethanol vapor.

\section{Experimental}

\subsection{Chemicals}

Urea, tin(Iv) chloride pentahydrate $\left(\mathrm{SnCl}_{4} \cdot 5 \mathrm{H}_{2} \mathrm{O}\right)$ and ammonia water $\left(\mathrm{NH}_{3} \cdot \mathrm{H}_{2} \mathrm{O}\right)$ were purchased from Sinopharm Chemical Reagent Co., Ltd. All reagents were of analytical grade without further purification.

${ }^{a}$ College of Chemistry and Chemical Engineering, Henan Polytechnic University, Jiaozuo 454000, PR China

${ }^{b}$ School of Safety Science and Engineering, State Key Laboratory Cultivation Base for Gas Geology and Gas Control, Henan Polytechnic University, Jiaozuo 454000, PR China. E-mail: yanwang@hpu.edu.cn; Fax: +86 391 3987440; Tel: +86 3913987440 ${ }^{c}$ School of Materials Science and Engineering, Henan Polytechnic University, Jiaozuo 454000, PR China.E-mail: zhangzy@hpu.edu.cn

\subsection{Preparation of $\mathrm{g}-\mathrm{C}_{3} \mathrm{~N}_{4} / \mathrm{SnO}_{2}$ composites}

Graphitic carbon nitride $\left(\mathrm{g}-\mathrm{C}_{3} \mathrm{~N}_{4}\right)$ was synthesized by the pyrolysis of urea in the muffle furnace, $20 \mathrm{~g}$ urea was put into an 
alumina crucible with a cover, then heated to $250{ }^{\circ} \mathrm{C}$ within $110 \mathrm{~min}$ and kept at $250^{\circ} \mathrm{C}$ for $1 \mathrm{~h}$. The further treatment was performed at 350 and $550{ }^{\circ} \mathrm{C}$ for $2 \mathrm{~h}$, respectively. The heating rate of the whole reaction was $2{ }^{\circ} \mathrm{C} \mathrm{min}^{-1}$. The yellow powder $(\mathrm{g}$ $\mathrm{C}_{3} \mathrm{~N}_{4}$ ) was collected. Typically, $5 \mathrm{wt} \% 2 \mathrm{D}$ g- $\mathrm{C}_{3} \mathrm{~N}_{4}$ modified $\mathrm{SnO}_{2}$ $\left(\mathrm{g}-\mathrm{C}_{3} \mathrm{~N}_{4}-5 \mathrm{P} / \mathrm{SnO}_{2}\right.$ ) was prepared with the following method. $0.1 \mathrm{~g}$ of $2 \mathrm{D} \mathrm{g}-\mathrm{C}_{3} \mathrm{~N}_{4}$ was dispersed in $130 \mathrm{~mL}$ DI water with ultrasonic treatment for $4 \mathrm{~h}$, and $4.65 \mathrm{~g} \mathrm{SnCl}_{4} \cdot 5 \mathrm{H}_{2} \mathrm{O}$ was added into 144 $\mathrm{mL}$ ethanol. Then, the $\mathrm{SnCl}_{4} \cdot 5 \mathrm{H}_{2} \mathrm{O}$ ethanol solution was slowly added into the $\mathrm{g}-\mathrm{C}_{3} \mathrm{~N}_{4}$ solution with magnetic stirring. Subsequently, $14 \mathrm{~mL} \mathrm{NH}_{3} \cdot \mathrm{H}_{2} \mathrm{O}$ was injected into the mixture solution. Finally, the mixture was transferred into a $500 \mathrm{~mL}$ Teflon-lined steel autoclave and the sealed tank was put into an oven and heated at $150{ }^{\circ} \mathrm{C}$ for $24 \mathrm{~h}$. The resulting product was separated by centrifuging and washed several times with DI water and ethanol. Then, the product was dried at $60{ }^{\circ} \mathrm{C}$ for $12 \mathrm{~h}$ to obtain the composite. According to this method, the $\mathrm{g}-\mathrm{C}_{3} \mathrm{~N}_{4} / \mathrm{SnO}_{2}$ composites with $2.5 \mathrm{wt} \%$ and $7.5 \mathrm{wt} \%$ g- $\mathrm{C}_{3} \mathrm{~N}_{4}$ modified $\mathrm{SnO}_{2}$ were also prepared and marked as $\mathrm{g}-\mathrm{C}_{3} \mathrm{~N}_{4}-2.5 \mathrm{P} / \mathrm{SnO}_{2}$ and $\mathrm{g}$ $\mathrm{C}_{3} \mathrm{~N}_{4}-7.5 \mathrm{P} / \mathrm{SnO}_{2}$. For the comparison purpose, the pure $\mathrm{SnO}_{2}$ particles were prepared without adding $2 \mathrm{D} g-\mathrm{C}_{3} \mathrm{~N}_{4}$.

\subsection{Characterization}

X-ray diffraction (XRD) analysis was performed on a Bruker-AXS D8 Advance diffractometer, with $\mathrm{CuK}_{\alpha}$ radiation at $40 \mathrm{kV}$ and 25 $\mathrm{mA}$ in a scanning range of $10-80^{\circ}(2 \theta)$. Thermogravimetry analysis (TG) was done on a NETZSCH STA449C Simultaneous Thermal Analyzer. Scanning electron microscope (SEM) images were performed on a FEI Quanta 250 FEG scanning electron microscope with an accelerating voltage of $30 \mathrm{kV}$. Transmission electron microscopy (TEM) analysis was performed on a JEOL JEM-2100 microscope, operating at $200 \mathrm{kV}$. The samples were dispersed in ethanol and treated with ultrasound for $5 \mathrm{~min}$, and then deposited on a copper grid coated with preformed holey carbon film. $\mathrm{N}_{2}$ adsorption-desorption isotherms were collected at liquid nitrogen temperature using a Quantachrome Autosorb-iQ sorption analyzer, and the sample was degassed at $150{ }^{\circ} \mathrm{C}$ for more than $6 \mathrm{~h}$. The specific surface areas $\left(S_{\mathrm{BET}}\right)$ of the samples were calculated following the multi-point BET (Brunauer-Emmett-Teller) procedure. The pore size distributions were determined from the adsorption branch of the isotherms using the DFT method. X-ray photoelectron spectroscopy (XPS) measurements were carried out on a Perkin-Elmer PHI 5600 spectrophotometer with the $\mathrm{MgK}_{\alpha}$ radiation, and the $\mathrm{C} 1 \mathrm{~s}$ peak was fixed at a binding energy of $284.6 \mathrm{eV}$.

\subsection{Fabrication and analysis of gas sensor}

The gas-sensing properties were investigated by using an intelligent gas sensing analysis system of CGS-4TPS from Beijing Elite Tech Co., Ltd. The as-prepared sample was mixed with several drops of distilled water to form a paste. The paste was then coated onto a ceramic substrate $(13.4 \mathrm{~mm} \times 7 \mathrm{~mm}$, screenprinted with $\mathrm{Ag}-\mathrm{Pd}$ comb-like electrodes) to obtain the resistance-type sensor. The schematic diagram of the typical gas sensor and the measuring principle were shown in Fig. 1. The test gases were injected into the closed chamber (with a volume

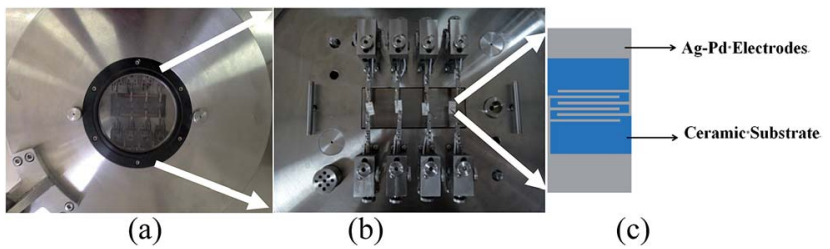

Fig. 1 (a) The appearance of the CGS-4TPS gas sensing test system, (b) the internal structure diagram of the test system, and (c) the structure diagram of the gas sensor substrate.

of $0.018 \mathrm{~m}^{3}$ ) by a microinjector. In order to improve the stability and repeatability, the sensor was aged at $200{ }^{\circ} \mathrm{C}$ for $12 \mathrm{~h}$. During the test, the operating temperature range was set at $200-380^{\circ} \mathrm{C}$, and the relative humidity was $40 \%$ in the test chamber. The gas response $(S)$ was defined as the ratio of $R_{\mathrm{a}} / R_{\mathrm{g}}$, where $R_{\mathrm{a}}$ and $R_{\mathrm{g}}$ were the resistances of sensor measured in air and in test gas, respectively. The response and recovery times were defined as the time required for a change in response reach $90 \%$ of the equilibrium value after injecting and removing the test gas.

\section{Results and discussion}

\subsection{Characterization of $2 \mathrm{D} g-\mathrm{C}_{3} \mathrm{~N}_{4}, \mathrm{SnO}_{2}$ and $\mathrm{g}-\mathrm{C}_{3} \mathrm{~N}_{4} / \mathrm{SnO}_{2}$ composites}

XRD patterns of the as-prepared samples are displayed in Fig. 2. As can be seen from Fig. 2(a), two diffraction peaks at $13.1^{\circ}$ and $27.5^{\circ}$ can be observed, which were accorded to the (100) and (002) plane of $g-\mathrm{C}_{3} \mathrm{~N}_{4}$. These two peaks could be due to the interlayer structure of tri-s-triazine unit with interplanar spacing and the conjugated aromatic system, respectively, ${ }^{29}$ which indicated that $\mathrm{g}-\mathrm{C}_{3} \mathrm{~N}_{4}$ was prepared successfully. Fig. 2(c-e) shows the XRD patterns of $\mathrm{g}-\mathrm{C}_{3} \mathrm{~N}_{4} / \mathrm{SnO}_{2}$ composites with different content of $\mathrm{g}-\mathrm{C}_{3} \mathrm{~N}_{4}$. It can be observed obviously that some diffraction peaks are seen at 2 theta of $26.61^{\circ}, 33.89^{\circ}, 37.94^{\circ}, 51.78^{\circ}, 65.93^{\circ}$, which are assigned to the (110), (101), (200), (211) and (301) planes of the tetragonal rutile structure $\mathrm{SnO}_{2}$ (JCPDS card no. 41-1445), respectively. However, compared with the XRD pattern

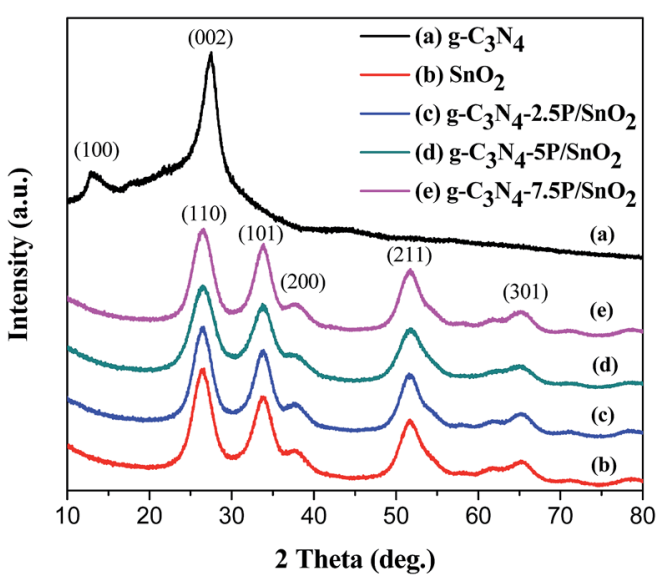

Fig. 2 XRD patterns of (a) $2 \mathrm{D} \mathrm{g}-\mathrm{C}_{3} \mathrm{~N}_{4}$, (b) $\mathrm{SnO}_{2}$, (c) $\mathrm{g}-\mathrm{C}_{3} \mathrm{~N}_{4}-2.5 \mathrm{P} / \mathrm{SnO}_{2}$, (d) $\mathrm{g}-\mathrm{C}_{3} \mathrm{~N}_{4}-5 \mathrm{P} / \mathrm{SnO} \mathrm{O}_{2}$ and (e) $\mathrm{g}-\mathrm{C}_{3} \mathrm{~N}_{4}-7.5 \mathrm{P} / \mathrm{SnO}_{2}$. 
of pure $\mathrm{SnO}_{2}$ in Fig. 2(b), no diffraction peaks of $\mathrm{g}-\mathrm{C}_{3} \mathrm{~N}_{4}$ can be observed in the patterns of $\mathrm{g}-\mathrm{C}_{3} \mathrm{~N}_{4} / \mathrm{SnO}_{2}$ composites. The main reason is the relatively low $\mathrm{g}-\mathrm{C}_{3} \mathrm{~N}_{4}$ content. Meanwhile, the diffraction peak of $\mathrm{g}-\mathrm{C}_{3} \mathrm{~N}_{4}$ at $27.5^{\circ}$ could probably be overlapped with the strong diffraction peak of $\mathrm{SnO}_{2}$ at $26.6^{\circ}$.

TG analysis was carried out from 20 to $700{ }^{\circ} \mathrm{C}$ with a heating rate of $10{ }^{\circ} \mathrm{C} \mathrm{min}^{-1}$ under air atmosphere to reveal the thermal stability of $\mathrm{g}-\mathrm{C}_{3} \mathrm{~N}_{4}, \mathrm{~g}-\mathrm{C}_{3} \mathrm{~N}_{4}-2.5 \mathrm{P} / \mathrm{SnO}_{2}, \mathrm{~g}-\mathrm{C}_{3} \mathrm{~N}_{4}-5 \mathrm{P} / \mathrm{SnO}_{2}$ and $\mathrm{g}-$ $\mathrm{C}_{3} \mathrm{~N}_{4}-7.5 \mathrm{P} / \mathrm{SnO}_{2}$ at different temperatures. As is shown in Fig. 3, in the range of $50-150{ }^{\circ} \mathrm{C}$ of the curves, moisture and impurities were lost a little part weight. The second agravity peak is between 150 and $350{ }^{\circ} \mathrm{C}$, which is due to the desorption of solvent. With increase of the temperature, a fast weight loss attributed to the decomposition of $\mathrm{g}-\mathrm{C}_{3} \mathrm{~N}_{4}$ was observed in the range of $450-620^{\circ} \mathrm{C}$. As shown in the profile of $\mathrm{g}-\mathrm{C}_{3} \mathrm{~N}_{4}-5 \mathrm{P} / \mathrm{SnO}_{2}$, the remanent content of the composite is $83 \%$ after the decomposition of $\mathrm{g}-\mathrm{C}_{3} \mathrm{~N}_{4}$. It is demonstrated that $\mathrm{g}-\mathrm{C}_{3} \mathrm{~N}_{4}$ has good thermal stability and can be used to modify the sensing materials when the operating temperature is below $400{ }^{\circ} \mathrm{C}$ and the $\mathrm{g}-\mathrm{C}_{3} \mathrm{~N}_{4}$ is not decomposed in the process of the gas sensing tests.

As is shown in Fig. 4(a), the morphologies of the as-prepared g- $\mathrm{C}_{3} \mathrm{~N}_{4}$ possess many wrinkles with overlap at the edges, which demonstrates that it possesses the two dimensional (2D) nanolamellar structure. From Fig. 4(b), we can find many irregular $\mathrm{SnO}_{2}$ particles with different sizes. The result in Fig. 4(c) indicates that some $\mathrm{SnO}_{2}$ particles are dispersed on the surface of $2 \mathrm{D} \mathrm{g}-\mathrm{C}_{3} \mathrm{~N}_{4}$ nanosheets. It shows that it is a suitable route to

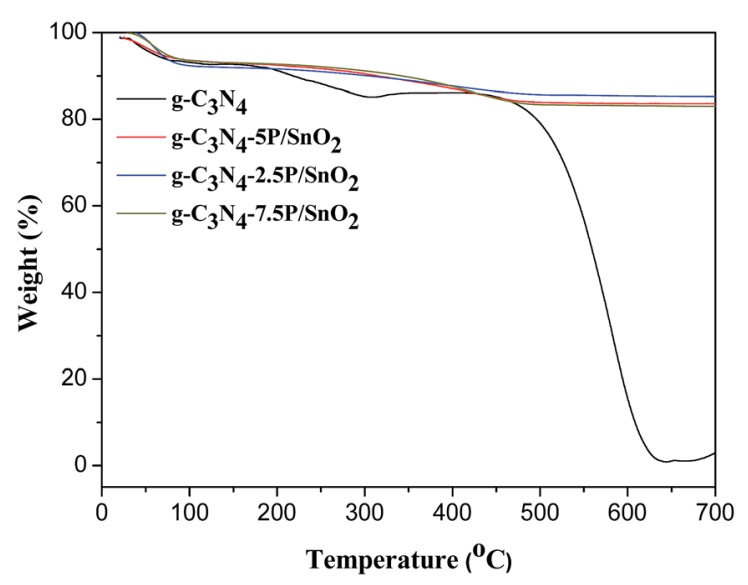

Fig. $3 \mathrm{TG}$ profiles of $2 \mathrm{D} g-\mathrm{C}_{3} \mathrm{~N}_{4}, \mathrm{~g}-\mathrm{C}_{3} \mathrm{~N}_{4}-2.5 \mathrm{P} / \mathrm{SnO}_{2}, \mathrm{~g}-\mathrm{C}_{3} \mathrm{~N}_{4}-5 \mathrm{P} /$ $\mathrm{SnO}_{2}$ and $\mathrm{g}-\mathrm{C}_{3} \mathrm{~N}_{4}-7.5 \mathrm{P} / \mathrm{SnO}_{2}$ composites.

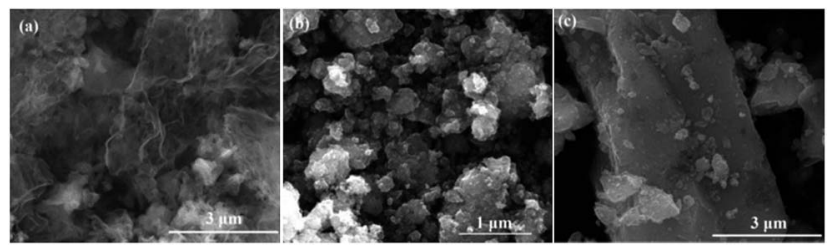

Fig. $4 \mathrm{SEM}$ images of (a) $2 \mathrm{D} \mathrm{g}-\mathrm{C}_{3} \mathrm{~N}_{4}$, (b) $\mathrm{SnO}_{2}$ particles, and (c) g$\mathrm{C}_{3} \mathrm{~N}_{4}-5 \mathrm{P} / \mathrm{SnO}_{2}$ composite. synthesize $\mathrm{g}-\mathrm{C}_{3} \mathrm{~N}_{4} / \mathrm{SnO}_{2}$ composites using the hydrothermal treatment. Fig. 5(a) shows a typical EDS spectrum of $g-\mathrm{C}_{3} \mathrm{~N}_{4}-5 \mathrm{P} /$ $\mathrm{SnO}_{2}$ composite. It is noted that four elements of $\mathrm{Sn}, \mathrm{O}, \mathrm{C}$ and $\mathrm{N}$ are synchronous existent in the same area observed in Fig. 5(bf). The percentage composition of the four elements of C, N, Sn and $\mathrm{O}$ are $5.25 \mathrm{wt} \%, 8.87 \mathrm{wt} \%, 56.0 \mathrm{wt} \%$ and $29.9 \mathrm{wt} \%$, respectively. The EDS mapping of $\mathrm{C}, \mathrm{N}, \mathrm{O}$ and $\mathrm{Sn}$ elements corresponding to Fig. 5(b) are displayed in Fig. 5(c), (d), (e) and (f), respectively. According to Fig. 5, the structural feature of $\mathrm{g}$ $\mathrm{C}_{3} \mathrm{~N}_{4}-5 \mathrm{P} / \mathrm{SnO}_{2}$ composite is that $2 \mathrm{D} \mathrm{g}-\mathrm{C}_{3} \mathrm{~N}_{4}$ and $\mathrm{SnO}_{2}$ particles are combined together effectively.

Furthermore, the $2 \mathrm{D} g-\mathrm{C}_{3} \mathrm{~N}_{4}$ and $\mathrm{g}-\mathrm{C}_{3} \mathrm{~N}_{4}-5 \mathrm{P} / \mathrm{SnO}_{2}$ composite were characterized by TEM. As shown in Fig. 6(a), the pure g$\mathrm{C}_{3} \mathrm{~N}_{4}$ is two dimensional nanosheets with many wrinkles. Fig. 6(b) displays that the $\mathrm{SnO}_{2}$ nanoparticles are highly distributed on the surface of the $2 \mathrm{D}$ g- $\mathrm{C}_{3} \mathrm{~N}_{4}$. Fig. 6 (c) shows the HRTEM image of $\mathrm{g}-\mathrm{C}_{3} \mathrm{~N}_{4}-5 \mathrm{P} / \mathrm{SnO}_{2}$ composite, it can be seen that the $\mathrm{SnO}_{2}$ nanoparticles with diameters of 3-5 $\mathrm{nm}$.

The porosity of the g- $\mathrm{C}_{3} \mathrm{~N}_{4}-2.5 \mathrm{P} / \mathrm{SnO}_{2}, \mathrm{~g}-\mathrm{C}_{3} \mathrm{~N}_{4}-5 \mathrm{P} / \mathrm{SnO}_{2}$ and g$\mathrm{C}_{3} \mathrm{~N}_{4}-7.5 \mathrm{P} / \mathrm{SnO}_{2}$ composites were verified by $\mathrm{N}_{2}$-sorption analysis. Fig. 7 depicts $\mathrm{N}_{2}$ adsorption-desorption isotherm and the corresponding pore size distribution of the composites. The isotherms (Fig. 7(a)) of the samples are of classical type IV, which possess the characteristic of mesoporous materials according to the IUPAC. The hysteresis loop in the range of 0.4$1.0\left(P / P_{0}\right)$ belong to the H3-type, which indicates the presence of mesoporous structure in the composites. ${ }^{30}$ The pore size distribution curves of the $\mathrm{g}-\mathrm{C}_{3} \mathrm{~N}_{4}-2.5 \mathrm{P} / \mathrm{SnO}_{2}, \mathrm{~g}-\mathrm{C}_{3} \mathrm{~N}_{4}-5 \mathrm{P} / \mathrm{SnO}_{2}$
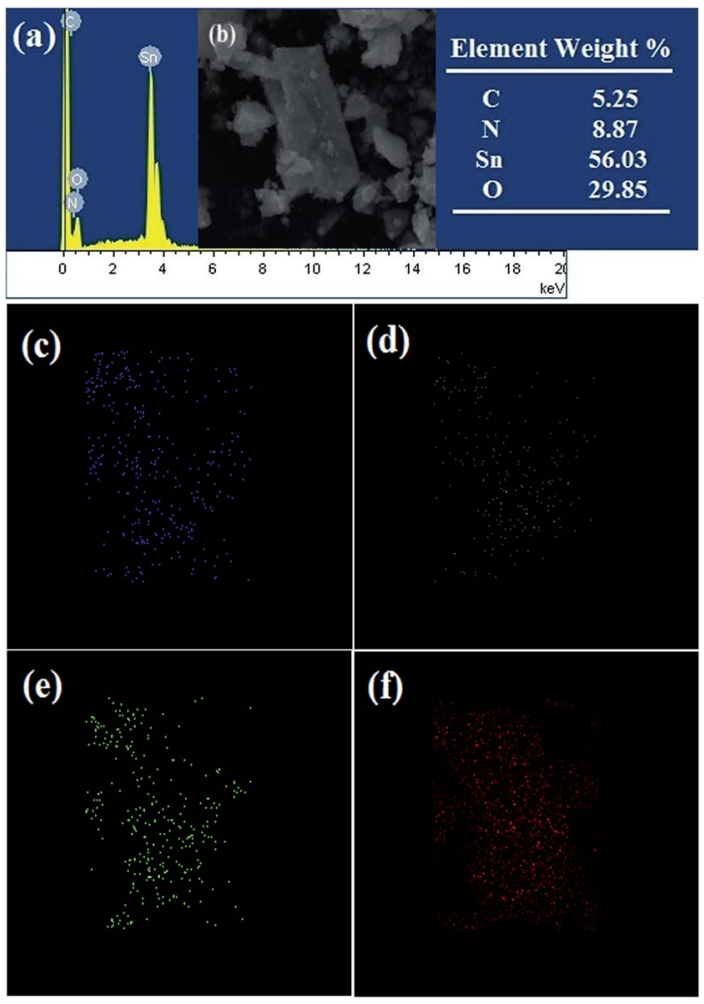

Fig. 5 (a) EDS spectra of the $\mathrm{g}-\mathrm{C}_{3} \mathrm{~N}_{4}-5 \mathrm{P} / \mathrm{SnO}_{2}$ composite, (b) SEM image and elements content for selected EDS area, and EDS mappings of $\mathrm{C}(\mathrm{c}), \mathrm{N}(\mathrm{d}), \mathrm{O}(\mathrm{e}), \mathrm{Sn}$ (f) element related to (b). 

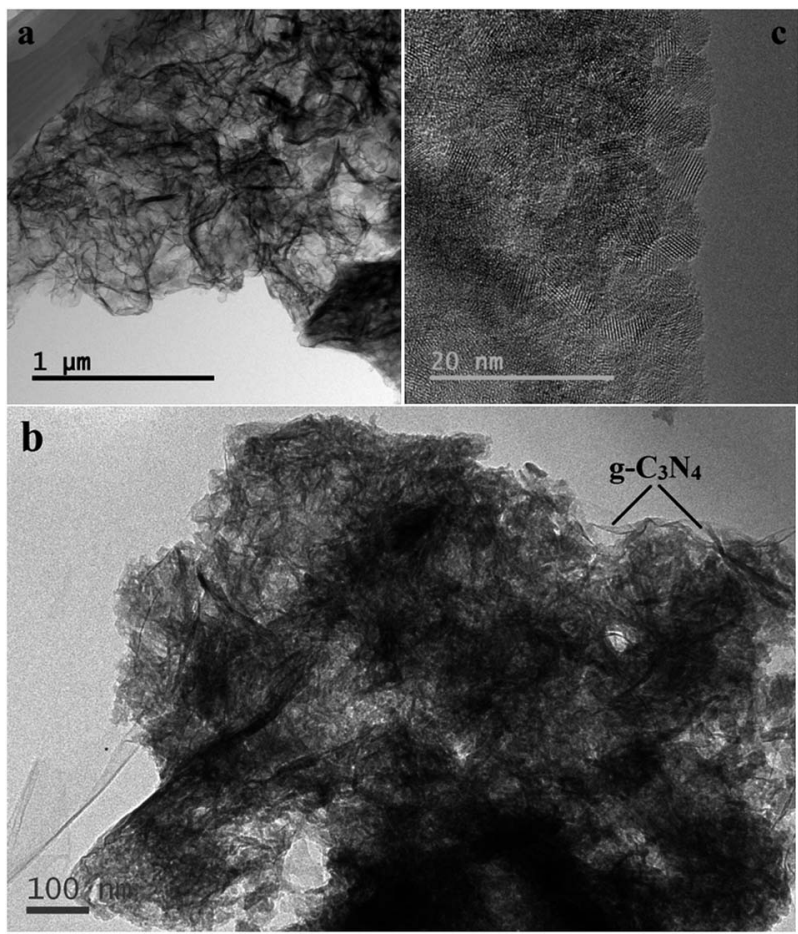

Fig. 6 TEM images of (a) $2 \mathrm{D} \mathrm{g}-\mathrm{C}_{3} \mathrm{~N}_{4}$, (b) g- $\mathrm{C}_{3} \mathrm{~N}_{4}-5 \mathrm{P} / \mathrm{SnO} \mathrm{O}_{2}$ composite, and (c) HRTEM image of the $\mathrm{g}-\mathrm{C}_{3} \mathrm{~N}_{4}-5 \mathrm{P} / \mathrm{SnO}_{2}$ composite.
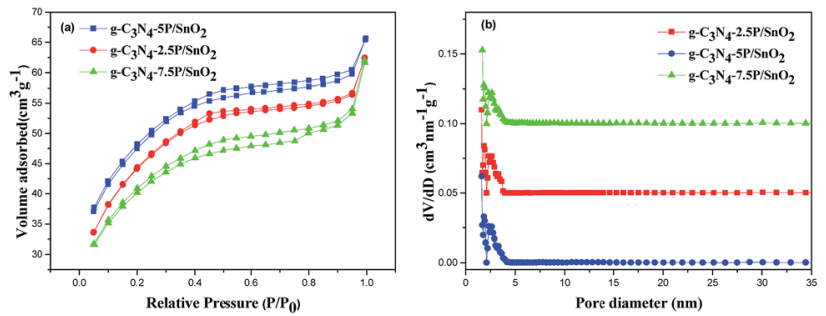

Fig. 7 (a) $\mathrm{N}_{2}$ adsorption-desorption isotherms and (b) the pore size distribution curves of the $\mathrm{g}-\mathrm{C}_{3} \mathrm{~N}_{4}-2.5 \mathrm{P} / \mathrm{SnO}_{2}, \mathrm{~g}-\mathrm{C}_{3} \mathrm{~N}_{4}-5 \mathrm{P} / \mathrm{SnO}_{2}$ and g$\mathrm{C}_{3} \mathrm{~N}_{4}-7.5 \mathrm{P} / \mathrm{SnO}_{2}$ composites. The volume adsorbed value was shifted by 3 units for the curve of data set $g-\mathrm{C}_{3} \mathrm{~N}_{4}-2.5 \mathrm{P} / \mathrm{SnO}_{2}$; The $\mathrm{dV} / \mathrm{d} D$ values were shifted by 0.05 and 0.1 units for the curves of data sets g$\mathrm{C}_{3} \mathrm{~N}_{4}-2.5 \mathrm{P} / \mathrm{SnO}_{2}$ and $\mathrm{g}-\mathrm{C}_{3} \mathrm{~N}_{4}-7.5 \mathrm{P} / \mathrm{SnO}_{2}$, respectively.

and $\mathrm{g}-\mathrm{C}_{3} \mathrm{~N}_{4}-7.5 \mathrm{P} / \mathrm{SnO}_{2}$ composites are shown in Fig. $7(\mathrm{~b})$. The curves depict that the samples have relatively small pores with a size distribution of $1-5 \mathrm{~nm}$ and the pores are concentrated upon $2.6 \mathrm{~nm}$ according to the DFT method. The specific surface area of $\mathrm{g}-\mathrm{C}_{3} \mathrm{~N}_{4}-2.5 \mathrm{P} / \mathrm{SnO}_{2}, \mathrm{~g}-\mathrm{C}_{3} \mathrm{~N}_{4}-5 \mathrm{P} / \mathrm{SnO}_{2}$ and $\mathrm{g}-\mathrm{C}_{3} \mathrm{~N}_{4}-7.5 \mathrm{P} /$ $\mathrm{SnO}_{2}$ composites are $117.6 \mathrm{~m}^{2} \mathrm{~g}^{-1}, 160.2 \mathrm{~m}^{2} \mathrm{~g}^{-1}$ and $134.8 \mathrm{~m}^{2}$ $\mathrm{g}^{-1}$, respectively. The highest surface area of $\mathrm{g}-\mathrm{C}_{3} \mathrm{~N}_{4}-5 \mathrm{P} / \mathrm{SnO}_{2}$ may make it possesses better gas sensing performance.

In order to investigate the heterojunction of the $\mathrm{g}-\mathrm{C}_{3} \mathrm{~N}_{4} / \mathrm{SnO}_{2}$ composite, the XPS technique was carried out to obtain the interactions between $\mathrm{SnO}_{2}$ and $\mathrm{g}-\mathrm{C}_{3} \mathrm{~N}_{4}$ (Fig. 8). Fig. 8(a) displays the survey scan spectra of $\mathrm{g}-\mathrm{C}_{3} \mathrm{~N}_{4}, \mathrm{SnO}_{2}$ and $\mathrm{g}-\mathrm{C}_{3} \mathrm{~N}_{4}-5 \mathrm{P} / \mathrm{SnO}_{2}$ composite. It is observed that $\mathrm{Sn}, \mathrm{O}, \mathrm{C}$ and $\mathrm{N}$ elements exist in the $\mathrm{g}-\mathrm{C}_{3} \mathrm{~N}_{4}-5 \mathrm{P} / \mathrm{SnO}_{2}$ composite and $\mathrm{Sn}, \mathrm{O}$ and $\mathrm{C}$ exist in $\mathrm{SnO}_{2}$.
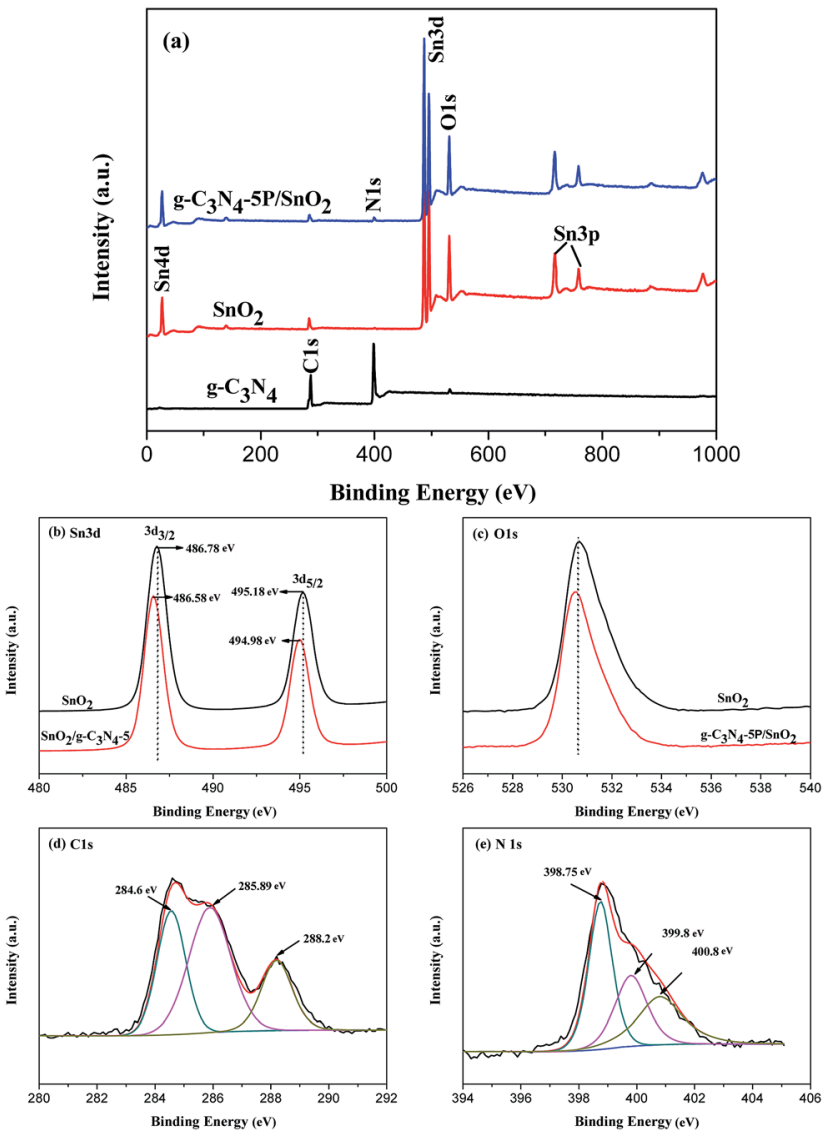

Fig. 8 XPS survey of $\mathrm{g}-\mathrm{C}_{3} \mathrm{~N}_{4}, \mathrm{SnO}_{2}$ and $\mathrm{g}-\mathrm{C}_{3} \mathrm{~N}_{4}-5 \mathrm{P} / \mathrm{SnO} \mathrm{O}_{2}$ samples: (a) the general scan spectrum, (b) Sn $3 d$ spectrum, (c) $O 1$ s spectrum, (d) C 1s spectrum, and (e) $\mathrm{N}$ 1s spectrum.

The $\mathrm{C}$ 1s peak from $\mathrm{SnO}_{2}$ is due to the adventitious carbon. The XPS spectra of the $\mathrm{g}-\mathrm{C}_{3} \mathrm{~N}_{4}$ sample shows only $\mathrm{C}$ and $\mathrm{N}$ elements. As shown in Fig. 8(b), two signal peaks of $\mathrm{Sn} 3 \mathrm{~d}$ in pure $\mathrm{SnO}_{2}$ at binding energies of $486.78 \mathrm{eV}$ and $495.18 \mathrm{eV}$ are corresponding to $\mathrm{Sn} 3 \mathrm{~d}_{3 / 2}$ and $\mathrm{Sn} 3 \mathrm{~d}_{5 / 2}$, respectively. However, these two signal peaks of $\mathrm{Sn} 3 \mathrm{~d}$ in $\mathrm{g}-\mathrm{C}_{3} \mathrm{~N}_{4}-5 \mathrm{P} / \mathrm{SnO}_{2}$ had a shift. The peak positions are changed to $486.58 \mathrm{eV}$ of $\mathrm{Sn} 3 \mathrm{~d}_{3 / 2}$ and $494.98 \mathrm{eV}$ of $\mathrm{Sn}$ $3 \mathrm{~d}_{5 / 2}$, respectively. This phenomenon can be attributed to the interactions between $\mathrm{g}-\mathrm{C}_{3} \mathrm{~N}_{4}$ and $\mathrm{Sn}$, and the heterojunction of interface region between $\mathrm{g}-\mathrm{C}_{3} \mathrm{~N}_{4}$ and $\mathrm{SnO}_{2}$. For high resolution XPS spectra, as is shown in Fig. 8(c), there are few distinction of $\mathrm{O} 1 \mathrm{~s}$ between $\mathrm{SnO}_{2}$ and $\mathrm{g}-\mathrm{C}_{3} \mathrm{~N}_{4}-5 \mathrm{P} / \mathrm{SnO}_{2}$. Fig. 8(d) displays the high resolution XPS spectra of $\mathrm{C} 1 \mathrm{~s}$. Three peaks for $\mathrm{C} 1 \mathrm{~s}$ binding energies exist at $284.6 \mathrm{eV}, 285.89 \mathrm{eV}$ and $288.2 \mathrm{eV}$, respectively. As is well known, the signal at $284.6 \mathrm{eV}$ corresponds to $\mathrm{sp}^{2} \mathrm{C}-\mathrm{C}$ bonds, while the signal at $285.89 \mathrm{eV}$ is identical to the combination of $\mathrm{C}-\mathrm{N}$ groups. And the signal at $288.2 \mathrm{eV}$ comes from the $\mathrm{sp}^{2} \mathrm{C}$ atoms from the aromatic rings $\mathrm{N}-\mathrm{C}=\mathrm{N}$. It can be seen from Fig. 8(e) that there are three signals with binding energies at 398.75, 399.8 and $400.8 \mathrm{eV}$, respectively. The peak at $398.75 \mathrm{eV}$ is ascribed to $\mathrm{sp}^{2}$-hybridized aromatic $\mathrm{N}$ bound to $\mathrm{C}$ atoms, the peak at $399.8 \mathrm{eV}$ comes from the tertiary $\mathrm{N}$ bonded to $\mathrm{C}$ atoms in the form of $\mathrm{N}-(\mathrm{C})_{3}$. And the peak at $400.8 \mathrm{eV}$ is related to the $\mathrm{N}-\mathrm{H}$ structure. 


\subsection{Gas-sensing properties}

A series of gas-sensing tests were performed to investigate the properties of the $\mathrm{g}-\mathrm{C}_{3} \mathrm{~N}_{4} / \mathrm{SnO}_{2}$ composites based sensors to ethanol vapor. For comparison, the pure $\mathrm{SnO}_{2}$ based sensor was also tested. The operating temperature can strongly affect the chemical reaction happened on the surface of sensing materials. Herein, the response values $\left(R_{\mathrm{a}} / R_{\mathrm{g}}\right)$ of the $\mathrm{g}-\mathrm{C}_{3} \mathrm{~N}_{4} / \mathrm{SnO}_{2}$ composite and the pure $\mathrm{SnO}_{2}$ based sensors to $500 \mathrm{ppm}$ ethanol vapor were measured at different operating temperature. As can be seen from Fig. 9(a), all the sensors exhibited the similar variation tendency with the increase of operating temperature. And all the sensors reached the maximum response value at $300{ }^{\circ} \mathrm{C}$ due to the chemisorbed oxygen species achieving the required energy to react with ethanol vapor molecules. And the reaction effectively happened on metal oxides semiconductor surface varying the resistance significantly. ${ }^{31}$ It can also be seen that the response values of the $\mathrm{g}-\mathrm{C}_{3} \mathrm{~N}_{4} / \mathrm{SnO}_{2}$ composite based sensors are much higher than that of the pure $\mathrm{SnO}_{2}$ based sensor. The response value of the composites increased with adding $\mathrm{g}-\mathrm{C}_{3} \mathrm{~N}_{4}$ content from 2.5 to $5 \mathrm{wt} \%$. However, the response value decreased with the further increased $\mathrm{g}-\mathrm{C}_{3} \mathrm{~N}_{4}$ content. The response values of the pure $\mathrm{SnO}_{2}, \mathrm{~g}-\mathrm{C}_{3} \mathrm{~N}_{4}-2.5 \mathrm{P} /$ $\mathrm{SnO}_{2}, \mathrm{~g}-\mathrm{C}_{3} \mathrm{~N}_{4}-5 \mathrm{P} / \mathrm{SnO}_{2}$ and $\mathrm{g}-\mathrm{C}_{3} \mathrm{~N}_{4}-7.5 \mathrm{P} / \mathrm{SnO}_{2}$ to $500 \mathrm{ppm}$ ethanol are 180, 201, 240, and 210, respectively. A suitable content of $\mathrm{g}-\mathrm{C}_{3} \mathrm{~N}_{4}$ in the composite is beneficial to the dispersity and preferable heterojunctional structure, which can be formed in the interface region between $2 \mathrm{D} \mathrm{g}-\mathrm{C}_{3} \mathrm{~N}_{4}$ and $\mathrm{SnO}_{2}$. However, when the $\mathrm{g}-\mathrm{C}_{3} \mathrm{~N}_{4}$ content in the composites exceed a value (e.g. 5 wt\% in this work), it may form the connection of bulk. As a result, the specific surface area of the composite decrease and there are reduced active sites for adsorption oxygen and ethanol gas, leading to the degradation of gas sensing properties. Consequently, the gas sensor performance increases at first and decreases when the $\mathrm{g}-\mathrm{C}_{3} \mathrm{~N}_{4}$ content in the composites increases. $^{32}$ The high content of $2 \mathrm{D} g-\mathrm{C}_{3} \mathrm{~N}_{4}$ may lead to the connection of the $\mathrm{g}-\mathrm{C}_{3} \mathrm{~N}_{4}$ nanosheets, which could form the micro electric bridges on the surface. The micro electric bridges may result in the semiconductor's resistance reduced. Therefore, the response value of the $\mathrm{g}-\mathrm{C}_{3} \mathrm{~N}_{4}-7.5 \mathrm{P} / \mathrm{SnO}_{2}$ composite sensor to ethanol vapor decreased. Thus, the optimum operating temperature is at $300{ }^{\circ} \mathrm{C}$ and the optimum g- $\mathrm{C}_{3} \mathrm{~N}_{4}$ content is $5 \mathrm{wt} \% 2 \mathrm{D}$ g- $\mathrm{C}_{3} \mathrm{~N}_{4}$ modified $\mathrm{SnO}_{2}$ composite. Therefore, all of
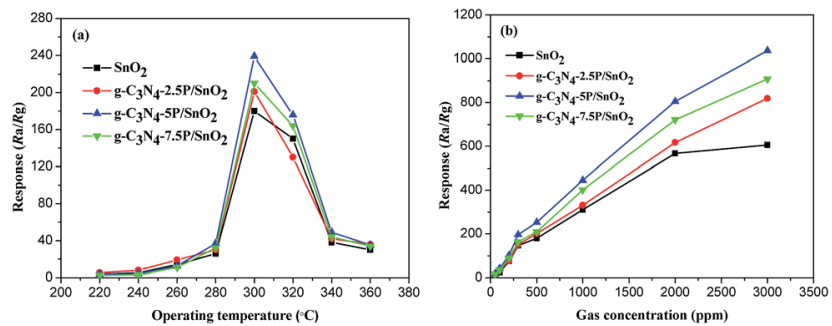

Fig. 9 The response values of the $\mathrm{SnO}_{2}, \mathrm{~g}-\mathrm{C}_{3} \mathrm{~N}_{4}-2.5 \mathrm{P} / \mathrm{SnO}_{2}, \mathrm{~g}-\mathrm{C}_{3} \mathrm{~N}_{4}-$ $5 \mathrm{P} / \mathrm{SnO}_{2}$ and $\mathrm{g}-\mathrm{C}_{3} \mathrm{~N}_{4}-7.5 \mathrm{P} / \mathrm{SnO}_{2}$ to $500 \mathrm{ppm}$ ethanol (a) under different operating temperature, (b) for different concentrations of ethanol at $300^{\circ} \mathrm{C}$. the further tests were carried on using the $\mathrm{g}-\mathrm{C}_{3} \mathrm{~N}_{4}-5 \mathrm{P} / \mathrm{SnO}_{2}$ composite sensor at $300{ }^{\circ} \mathrm{C}$. Fig. 9(b) shows the response values of all the sensors at different concentrations of ethanol at $300{ }^{\circ} \mathrm{C}$. It can be seen that the response values increased promptly with the increasing of ethanol concentration in the range of 50-2000 ppm. However, the response values increased slowly when the ethanol concentration is in the range of 20003000 ppm. It can be concluded that the adsorption of these sensors to ethanol has reached approximately saturation. The response values of these sensors to ethanol at $300{ }^{\circ} \mathrm{C}$ from high to low are g- $\mathrm{C}_{3} \mathrm{~N}_{4}-5 \mathrm{P} / \mathrm{SnO}_{2}, \mathrm{~g}-\mathrm{C}_{3} \mathrm{~N}_{4}-7.5 \mathrm{P} / \mathrm{SnO}_{2}, \mathrm{~g}-\mathrm{C}_{3} \mathrm{~N}_{4}-2.5 \mathrm{P} / \mathrm{SnO}_{2}$ and $\mathrm{SnO}_{2}$, respectively.

Fig. 10(a) displays the continuous response-recover curves of the pure $\mathrm{SnO}_{2}$ and $\mathrm{g}-\mathrm{C}_{3} \mathrm{~N}_{4}-5 \mathrm{P} / \mathrm{SnO}_{2}$ composite based sensors to different ethanol concentrations at $300{ }^{\circ} \mathrm{C}$. Each responserecovery cycle was taken up about $500 \mathrm{~s}$ with a response interval of $250 \mathrm{~s}$ and a recovery interval of $250 \mathrm{~s}$. It can be seen that the response values of the both sensors increased with the increase of ethanol concentration in the range of 50-5000 ppm. As seen in Fig. $10(\mathrm{a})$, the $\mathrm{g}-\mathrm{C}_{3} \mathrm{~N}_{4}-5 \mathrm{P} / \mathrm{SnO}_{2}$ composite sensor exhibited much higher response value than that of pure $\mathrm{SnO}_{2}$ sensor to ethanol vapor in the range of 50-5000 $\mathrm{ppm}$. The response value of the $\mathrm{g}-\mathrm{C}_{3} \mathrm{~N}_{4}-5 \mathrm{P} / \mathrm{SnO}_{2}$ composite sensor to $5000 \mathrm{ppm}$ ethanol reached about 1900 , which is nearly two times higher than that of the pure $\mathrm{SnO}_{2}$ sensor. Response-recovery time is one of the most critical influential factor on the response of gas sensor. Fig. 10(b) shows the response-recovery time of the $g-\mathrm{C}_{3} \mathrm{~N}_{4}-5 \mathrm{P} /$ $\mathrm{SnO}_{2}$ composite sensor to $2000 \mathrm{ppm}$ ethanol at $300{ }^{\circ} \mathrm{C}$. As seen in Fig. 10(b), the response promptly reached the maximum value when the $\mathrm{g}-\mathrm{C}_{3} \mathrm{~N}_{4}-5 \mathrm{P} / \mathrm{SnO}_{2}$ composite sensor was exposed to ethanol vapor. And the response time and the recovery time are $15 \mathrm{~s}$ and $38 \mathrm{~s}$, respectively.

The repeatability of sensing material plays an important role in the practical application of gas sensor. The repeatability of
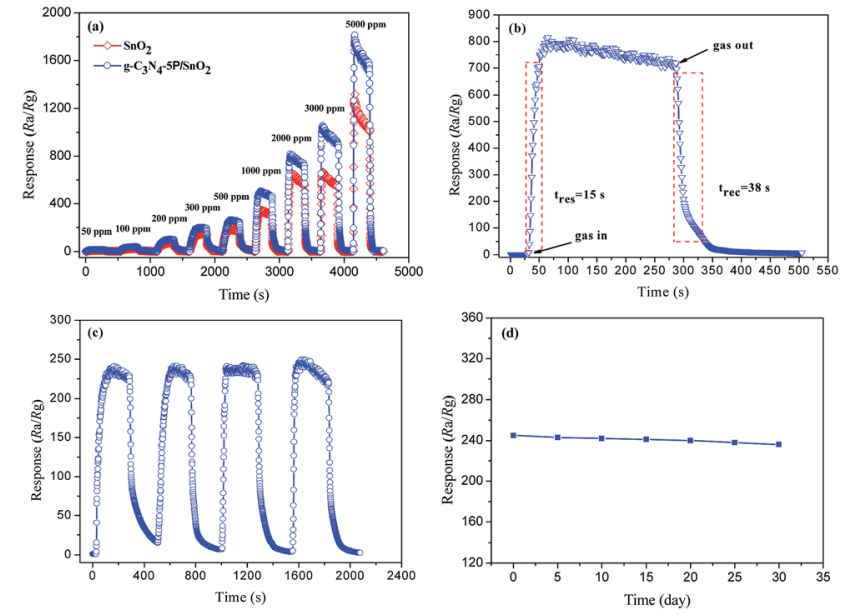

Fig. 10 (a) Real time response curves of the pure $\mathrm{SnO}_{2}$ and $\mathrm{g}-\mathrm{C}_{3} \mathrm{~N}_{4}$ $5 \mathrm{P} / \mathrm{SnO}_{2}$ composite sensors to ethanol in the range of $50-5000 \mathrm{ppm}$, (b) response-recovery time characteristics of the $\mathrm{g}-\mathrm{C}_{3} \mathrm{~N}_{4}-5 \mathrm{P} / \mathrm{SnO}_{2}$ composite sensor to $2000 \mathrm{ppm}$ ethanol at $300{ }^{\circ} \mathrm{C}$, (c) repeatability and (d) stability behaviors of the $\mathrm{g}-\mathrm{C}_{3} \mathrm{~N}_{4}-5 \mathrm{P} / \mathrm{SnO}_{2}$ composite sensor to $500 \mathrm{ppm}$ ethanol at $300^{\circ} \mathrm{C}$. 
the $\mathrm{g}-\mathrm{C}_{3} \mathrm{~N}_{4}-5 \mathrm{P} / \mathrm{SnO}_{2}$ composite based sensor to $500 \mathrm{ppm}$ ethanol vapor was performed at $300{ }^{\circ} \mathrm{C}$. Fig. 10 (c) shows the responserecovery cycle curves. And the response values of the tests are 239, 241, 240 and 245, respectively. The $\mathrm{g}-\mathrm{C}_{3} \mathrm{~N}_{4}-5 \mathrm{P} / \mathrm{SnO}_{2}$ composite sensor shows an excellent repeatable performance for ethanol gas sensing. Moreover, the stability of the $\mathrm{g}^{-} \mathrm{C}_{3} \mathrm{~N}_{4}-5 \mathrm{P} /$ $\mathrm{SnO}_{2}$ composite based sensor was also investigated and a longterm response value was measured. Fig. 10(d) shows the response value of the $\mathrm{g}-\mathrm{C}_{3} \mathrm{~N}_{4}-5 \mathrm{P} / \mathrm{SnO}_{2}$ composite based sensor was exposed to $500 \mathrm{ppm}$ ethanol for 30 days. The response value was measured every 5 days and the response value was nearly kept at 240. It indicated that the $\mathrm{g}-\mathrm{C}_{3} \mathrm{~N}_{4}-5 \mathrm{P} / \mathrm{SnO}_{2}$ composite sensor had a good stability, which could be one of the potential candidates for ethanol gas sensor. Selectivity is another pivotal criterion of gas sensor.

The selectivity of the pure $\mathrm{SnO}_{2}$ and $\mathrm{g}-\mathrm{C}_{3} \mathrm{~N}_{4}-5 \mathrm{P} / \mathrm{SnO}_{2}$ composite sensors to five different $500 \mathrm{ppm}$ gases at $300{ }^{\circ} \mathrm{C}$ was investigated. The five different gases are respectively ethanol, methanol, formaldehyde, acetone and toluene. The response values were measured and the results are shown in Fig. 11. It is observed that the g- $\mathrm{C}_{3} \mathrm{~N}_{4}-5 \mathrm{P} / \mathrm{SnO}_{2}$ composite sensor has a better selectivity to ethanol than the pure $\mathrm{SnO}_{2}$ sensor in the five different gases at $300{ }^{\circ} \mathrm{C}$.

The performances of different sensing materials are listed in Table 1 . As can be seen from Table 1 , according to the literature, the response values of $\mathrm{SnO}_{2} @ \mathrm{MoS}_{2},{ }^{22} \mathrm{ZnO} /$ graphene, ${ }^{8}$ In-doped $\mathrm{SnO}_{2},{ }^{23} \mathrm{SnO}_{2} /$ graphene ${ }^{24}$ were $160,280,80,38.58$, respectively. In this work, the response value of $5 \mathrm{wt} \% 2 \mathrm{D} \mathrm{g}-\mathrm{C}_{3} \mathrm{~N}_{4}$ modified $\mathrm{SnO}_{2}$ to $500 \mathrm{ppm}$ of ethanol vapor was 240 at $300{ }^{\circ} \mathrm{C}$. Therefore, the $\mathrm{g}-\mathrm{C}_{3} \mathrm{~N}_{4} / \mathrm{SnO}_{2}$ composites show the excellent sensing properties to ethanol vapor, which have a great potential application.

\subsection{Gas sensing mechanism of the $\mathrm{g}-\mathrm{C}_{3} \mathrm{~N}_{4} / \mathrm{SnO}_{2}$ composites}

In general, for the $\mathrm{g}-\mathrm{C}_{3} \mathrm{~N}_{4} / \mathrm{SnO}_{2}$ composites, the incorporation of $2 \mathrm{D} g-\mathrm{C}_{3} \mathrm{~N}_{4}$ plays an important role on preventing the aggregation of $\mathrm{SnO}_{2}$ particles and forms a large surface area structure, which is beneficial to the adsorption and diffusion process of ethanol molecules. And the $2 \mathrm{D} g-\mathrm{C}_{3} \mathrm{~N}_{4}$ nanosheets can

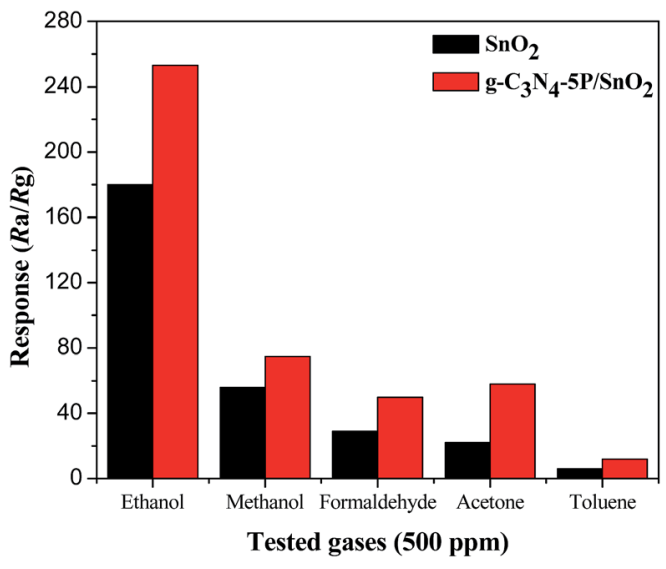

Fig. 11 Comparison of the response values of the pure $\mathrm{SnO}_{2}$ and the $\mathrm{g}-\mathrm{C}_{3} \mathrm{~N}_{4}-5 \mathrm{P} / \mathrm{SnO}_{2}$ composite sensors to $500 \mathrm{ppm}$ different gases at $300^{\circ} \mathrm{C}$.
Table 1 The comparative analysis of the sensing performance between this work and previously reported results

\begin{tabular}{lllll}
\hline $\begin{array}{l}\text { Sensing } \\
\text { materials }\end{array}$ & $\begin{array}{l}\text { Ethanol } \\
\text { concentration } \\
(\mathrm{ppm})\end{array}$ & $\begin{array}{l}\text { Temperature } \\
\left({ }^{\circ} \mathrm{C}\right)\end{array}$ & $\begin{array}{l}\text { Response } \\
\left(R_{\mathrm{a}} / R_{\mathrm{g}}\right)\end{array}$ & Ref. \\
\hline $\mathrm{SnO}_{2} @ \mathrm{MoS}_{2}$ & 500 & 280 & 160 & 22 \\
$\mathrm{ZnO} /$ graphene & 500 & 400 & 280 & 8 \\
In-doped $\mathrm{SnO}_{2}$ & 500 & 300 & 80 & 23 \\
$\mathrm{SnO}_{2} /$ graphene & 600 & 27 & 38.58 & 24 \\
$\mathrm{SnO}_{2} / \mathrm{g}^{-} \mathrm{C}_{3} \mathrm{~N}_{4}$ & 500 & 300 & 240 & This \\
& & & & work
\end{tabular}

provide more active sites to adsorb $\mathrm{O}_{2}$ molecules and ethanol gas molecules. The improved gas sensing performance of the $\mathrm{g}$ $\mathrm{C}_{3} \mathrm{~N}_{4} / \mathrm{SnO}_{2}$ composite sensor to ethanol could be mainly attributed to the heterojunction of interface region between $\mathrm{g}$ $\mathrm{C}_{3} \mathrm{~N}_{4}$ and $\mathrm{SnO}_{2}$ and the interactions between $\mathrm{Sn}$ and $\mathrm{g}-\mathrm{C}_{3} \mathrm{~N}_{4}$. According to the XPS result, the shift of Sn 3d signal peaks illustrates that there are the interactions between $\mathrm{Sn}$ and $\mathrm{g}$ $\mathrm{C}_{3} \mathrm{~N}_{4}$. The electrical properties at the heterojunctions changes while ethanol gas molecules pass through the interface region between $\mathrm{g}-\mathrm{C}_{3} \mathrm{~N}_{4}$ and $\mathrm{SnO}_{2}$. This coadjacent retiform structure could provide higher efficiency for the gas adsorption and diffusion between $\mathrm{SnO}_{2}$ and $\mathrm{g}-\mathrm{C}_{3} \mathrm{~N}_{4}$. Both of $\mathrm{SnO}_{2}$ and $\mathrm{g}-\mathrm{C}_{3} \mathrm{~N}_{4}$ are n-type semiconductor. The band gap are $3.71 \mathrm{eV}$ and $2.7 \mathrm{eV}$, respectively. The conduction band level of $\mathrm{g}-\mathrm{C}_{3} \mathrm{~N}_{4}$ is negative than $\mathrm{SnO}_{2}$. When $\mathrm{SnO}_{2}$ and $\mathrm{g}-\mathrm{C}_{3} \mathrm{~N}_{4}$ were combined, they formed a heterojunction structure. The electrons will inflow from the conduction band of $\mathrm{g}-\mathrm{C}_{3} \mathrm{~N}_{4}$ to the conduction band of $\mathrm{SnO}_{2}$, leading to a higher potential barrier. As a result, the electrons and holes are separated. ${ }^{33}$ Meanwhile, the heterojunction structure may suppress the recombination of electron-hole and urge electrons to transfer quickly from ethanol vapour to the surface of $\mathrm{SnO}_{2} / \mathrm{g}-\mathrm{C}_{3} \mathrm{~N}_{4}$. Therefore, this lead to a higher response because of the increased conductivity of the heterojunction structure. ${ }^{32}$ In addition, surface adsorbed oxygen theory is also used to explain gas sensing mechanism. Oxygen molecules would adsorb on surface of $\mathrm{SnO}_{2}$ and capture electrons from the conduction band of $\mathrm{SnO}_{2}$ when the sensor was exposed in air (eqn (1)). Then oxygen molecules were ionized to $\mathrm{O}^{2-}, \mathrm{O}^{-}$and $\mathrm{O}_{2}{ }^{-}$, and the formation of depletion layers led to the increase of resistance of the composite sensor. Nevertheless, when the sensor was exposed into the ethanol gas, the ethanol molecules would react with oxygen ions absorbed on the surface of the sensor. As displayed in eqn (2) and (3), the ethanol molecules were oxidized into acetaldehyde and eventually turned into carbon dioxide and water. As a result, the trapped electrons released back to the depletion layer of the sensing film, resulting in the decrease of the resistance of the composite sensor.

$$
\begin{gathered}
\mathrm{O}_{2}+\mathrm{e}^{-} \rightarrow \mathrm{O}_{2}^{-} \\
2 \mathrm{CH}_{3} \mathrm{CH}_{2} \mathrm{OH}+\mathrm{O}_{2}^{-} \rightarrow 2 \mathrm{CH}_{3} \mathrm{CHO}+2 \mathrm{H}_{2} \mathrm{O}+\mathrm{e}^{-} \\
2 \mathrm{CH}_{3} \mathrm{CHO}+5 \mathrm{O}_{2}^{-} \rightarrow 4 \mathrm{CO}_{2}+4 \mathrm{H}_{2} \mathrm{O}+5 \mathrm{e}^{-}
\end{gathered}
$$




\section{Conclusions}

In summary, the $\mathrm{g}-\mathrm{C}_{3} \mathrm{~N}_{4} / \mathrm{SnO}_{2}$ composites were prepared by a facile method through hydrothermal treatment. And it was found that the sensor based on $\mathrm{g}-\mathrm{C}_{3} \mathrm{~N}_{4} / \mathrm{SnO}_{2}$ composite showed high sensitivity and excellent selectivity for detection of ethanol vapor. At $500 \mathrm{ppm}$ of ethanol vapor, the response value $\left(R_{\mathrm{a}} / R_{\mathrm{g}}\right)$ of

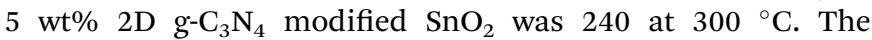
improved sensing properties of the $\mathrm{g}-\mathrm{C}_{3} \mathrm{~N}_{4} / \mathrm{SnO}_{2}$ composites are mainly attributed to the large specific surface and the modified electronic characteristics. Considering its facile effective synthesis approach, the $\mathrm{g}-\mathrm{C}_{3} \mathrm{~N}_{4} / \mathrm{SnO}_{2}$ composite will be an ideal candidate for ethanol gas sensor application, optic devices and photocatalysis.

\section{Acknowledgements}

This work was supported by the National Natural Science Foundation of China (51404097, 51504083, U1404613), Program for Science \& Technology Innovation Talents in Universities of Henan Province (17HASTIT029), the Research Foundation for Youth Scholars of Higher Education of Henan Province (2016GGJS-040), Natural Science Foundation of Henan Province of China (162300410113), China Postdoctoral Science Foundation funded project (2016M592290), the Fundamental Research Funds for the Universities of Henan Province (NSFRF1606, NSFRF140101), Program for innovative Research of Henan Province (16IRTSTHN005), and Foundation for Distinguished Young Scientists of Henan Polytechnic University (J2016-2, J2017-3).

\section{Notes and references}

1 D. Zhang, J. Liu, H. Chang, A. Liu and B. Xia, Characterization of a hybrid composite of $\mathrm{SnO}_{2}$ nanocrystal-decorated reduced graphene oxide for ppmlevel ethanol gas sensing application, $R S C A d v ., 2015,5$, 18666-18672.

2 O. Korostynska, A. Mason, M. Ortoneda-Pedrolam and A. AlShamma'a, Electromagnetic wave sensing of $\mathrm{NO}_{3}$ and COD concentrations for real-time environmental and industrial monitoring, Sens. Actuators, B, 2014, 198, 49-54.

3 D. Zhang, J. Tong, B. Xia and Q. Xue, Ultrahigh performance humidity sensor based on layer-by-layer self-assembly of graphene oxide/polyelectrolyte nanocomposite film, Sens. Actuators, B, 2014, 203, 263-270.

4 S. T. Navale, A. T. Mane, M. A. Chougule, N. M. Shinde, J. Kim and V. B. Patil, Highly selective and sensitive CdS thin film sensors for detection of $\mathrm{NO}_{2}$ gas, $R S C A d v$., 2014, 4, 4454744554 .

$5 \mathrm{H}$. Zhang, J. Feng, T. Fei, S. Liu and T. Zhang, $\mathrm{SnO}_{2}$ nanoparticles-reduced graphene oxide nanocomposites for $\mathrm{NO}_{2}$ sensing at low operating temperature, Sens. Actuators, $B, 2014,190,472-478$.

6 N. Karmakar, R. Fernandes, S. Jain, U. V. Patil, N. G. Shimpi, N. V. Bhat and D. C. Kothari, Room temperature $\mathrm{NO}_{2}$ gas sensing properties of $p$-toluenesulfonic acid doped silver- polypyrrole nanocomposite, Sens. Actuators, B, 2017, 242, 118-126.

7 F. Perrozzi, S. M. Emamjomeh, V. Paolucci, G. Taglieri, L. Ottaviano and C. Cantalini, Thermal stability of $\mathrm{WS}_{2}$ flakes and gas sensing properties of $\mathrm{WS}_{2} / \mathrm{WO}_{3}$ composite to $\mathrm{H}_{2}, \mathrm{NH}_{3}$ and $\mathrm{NO}_{2}$, Sens. Actuators, B, 2017, 243, 812-822.

8 S. Liang, J. Zhu, J. Ding, H. Bi, P. Yao, Q. Han and X. Wang, Deposition of cocoon-like $\mathrm{ZnO}$ on graphene sheets for improving gas-sensing properties to ethanol, Appl. Surf. Sci., 2015, 357, 1593-1600.

9 Y. Chen, X. Li, X. Li, J. Wang and Z. Tang, UV activated hollow ZnO microspheres for selective ethanol sensors at low temperatures, Sens. Actuators, B, 2016, 232, 158-164.

10 A. Umar, J.-H. Lee, R. Kumar, O. Al-Dossary, A. A. Ibrahim and S. Baskoutas, Development of highly sensitive and selective ethanol sensor based on lance-shaped $\mathrm{CuO}$ nanostructures, Mater. Des., 2016, 105, 16-24.

11 S. Park, H. Kheel, G.-J. Sun, S. K. Hyun, S. E. Park and C. Lee, Ethanol sensing properties of Au-functional NiO nanoparticles, Bull. Korean Chem. Soc., 2016, 37, 713-719.

12 C. Stella, N. Soundararajan and K. Ramachandran, Undoped and $\mathrm{Mn}$-doped $\mathrm{Co}_{3} \mathrm{O}_{4}$ nanorods for ethanol sensing, J. Mater. Sci.: Mater. Electron., 2015, 26, 4178-4184.

13 S. Liang, J. Zhu, C. Wang, S. Yu, H. Bi, X. Liu and X. Wang, Fabrication of $\alpha-\mathrm{Fe}_{2} \mathrm{O}_{3}$ @graphene nanostructures for enhanced gas-sensing property to ethanol, Appl. Surf. Sci., 2014, 292, 278-284.

14 S. Cao, C. Zhao, T. Han and L. Peng, Hydrothermal synthesis, characterization and gas sensing properties of the $\mathrm{WO}_{3}$ nanofibers, Mater. Lett., 2016, 169, 17-20.

15 R. Chandiramouli and B. G. Jeyaprakash, Operating temperature dependent ethanol and formaldehyde detection of spray deposited mixed $\mathrm{CdO}$ and $\mathrm{MnO}_{2}$ thin films, RSC Adv., 2015, 5, 43930-43940.

16 Y. V. Kaneti, J. Yue, J. Moriceau, C. Chen, M. Liu, Y. Yuan, $\mathrm{X}$. Jiang and A. Yu, Experimental and theoretical studies on noble metal decorated tin oxide flower-like nanorods with high ethanol sensing performance, Sens. Actuators, B, 2015, 219, 83-93.

17 V. Srivastava and K. Jain, At room temperature graphene/ $\mathrm{SnO}_{2}$ is better than $\mathrm{MWCNT} / \mathrm{SnO}_{2}$ as $\mathrm{NO}_{2}$ gas sensor, Mater. Lett., 2015, 169, 28-32.

18 Z. Song, Z. Wei, B. Wang, Z. Luo, S. Xu, W. Zhang, H. Yu, M. Li, Z. Huang, J. Zang, F. Yi and H. Liu, Sensitive RoomTemperature $\mathrm{H}_{2} \mathrm{~S}$ Gas Sensors Employing $\mathrm{SnO}_{2}$ Quantum Wire/Reduced Graphene Oxide Nanocomposites, Chem. Mater., 2016, 28, 1205-1212.

19 S. Mao, S. Cui, G. Lu, K. Yu, Z. Wen and J. Chen, Tuning gassensing properties of reduced graphene oxide using tin oxide nanocrystals, J. Mater. Chem., 2012, 22, 11009-11013.

20 S. Das and V. Jayaraman, $\mathrm{SnO}_{2}$ : A comprehensive review on structures and gas sensors, Prog. Mater. Sci., 2014, 66, 112255.

21 M. Narjinary, P. Rana, A. Sen and M. Pal, Enhanced and selective acetone sensing properties of $\mathrm{SnO}_{2}$-MWCNT nanocomposites: Promising materials for diabetes sensor, Mater. Des., 2017, 115, 158-164. 
22 H. Yan, P. Song, S. Zhang, Z. Yang and Q. Wang, Dispersed $\mathrm{SnO}_{2}$ nanoparticles on $\mathrm{MoS}_{2}$ nanosheets for superior gassensing performances to ethanol, $R S C A d v$., 2015, 5, 79593-79599.

23 K. Inyawilert, A. Wisitsoraat, C. Sriprachaubwong, A. Tuantranont, S. Phanichphant and C. Liewhiran, Rapid ethanol sensor based on electrolytically-exfoliated grapheneloaded flame-made In-doped $\mathrm{SnO}_{2}$ composite film, Sens. Actuators, B, 2015, 209, 40-55.

24 M. T. V. O. Jayaweera, R. C. L. De Silva, I. R. M. Kottegoda and S. R. D. Rosa, Synthesis, characterization and ethanol vapor sensing performance of $\mathrm{SnO}_{2} /$ Graphene composite film, $J$. Phys., 2015, 15, 1-10.

25 H. Dai, S. Zhang, G. Xu, Y. Peng, L. Gong, X. Li, Y. Li, Y. Lin and G. Chen, Highly photoactive heterojunction based on $\mathrm{g}$ $\mathrm{C}_{3} \mathrm{~N}_{4}$ nanosheets decorated with dendritic zinc(II) phthalocyanine through axial coordination and its ultrasensitive enzyme-free sensing of choline, RSC Adv., 2014, 4, 58226-58230.

26 Q. Lu, J. Zhang, X. Liu, Y. Wu, R. Yuan and S. Chen, Enhanced electrochemiluminescence sensor for detecting dopamine based on gold nanoflower@graphitic carbon nitride polymer nanosheet-polyaniline hybrids, Analyst, 2014, 139, 6556-6562.

27 X. She, H. Xu, H. Wang, J. Xia, Y. Song, J. Yan, Y. Xu, Q. Zhang, D. Du and H. Li, Controllable synthesis of $\mathrm{CeO}_{2} /$ g- $\mathrm{C}_{3} \mathrm{~N}_{4}$ composites and their applications in the environment, Dalton Trans., 2015, 44, 7021-7031.

28 X. L. Zhang, C. Zheng, S. S. Guo, J. Li, H. H. Yang and G. Chen, Turn-on fluorescence sensor for intracellular imaging of glutathione using $\mathrm{g}-\mathrm{C}_{3} \mathrm{~N}_{4}$ nanosheet- $\mathrm{MnO}_{2}$ sandwich nanocomposite, Anal. Chem., 2014, 86, 3426-3434.

29 B. Zeng, L. Zhang, X. Wan, H. Song and Y. Lv, Fabrication of $\alpha-\mathrm{Fe}_{2} \mathrm{O}_{3} / \mathrm{g}-\mathrm{C}_{3} \mathrm{~N}_{4}$ composites for cataluminescence sensing of $\mathrm{H}_{2} \mathrm{~S}$, Sens. Actuators, B, 2015, 211, 370-376.

30 J. L. Cao, Y. Wang, T. Y. Zhang, S. H. Wu and Z. Y. Yuan, Preparation, characterization and catalytic behavior of nanostructured mesoporous $\mathrm{CuO} / \mathrm{Ce}_{0.8} \mathrm{Zr}_{0.2} \mathrm{O}_{2}$ catalysts for low-temperature CO oxidation, Appl. Catal., B, 2008, 78, 120-128.

31 Y. Xiao, Q. Yang, Z. Wang, R. Zhang, Y. Gao, P. Sun, Y. Sun and $\mathrm{G}$. Lu, Improvement of $\mathrm{NO}_{2}$ gas sensing performance based on discoid tin oxide modified by reduced graphene oxide, Sens. Actuators, B, 2016, 227, 419-426.

32 Y. Zhang, D. Zhang, W. Guo and S. Chen, The $\alpha-\mathrm{Fe}_{2} \mathrm{O}_{3} / g-\mathrm{C}_{3} \mathrm{~N}_{4}$ heterostructural nanocomposites with enhanced ethanol gas sensing performance, J. Alloys Compd., 2016, 685, 84-90.

33 Y. Zang, L. Li, X. Li, R. Lin and G. Li, Synergistic collaboration of $\mathrm{g}-\mathrm{C}_{3} \mathrm{~N}_{4} / \mathrm{SnO}_{2}$ composites for enhanced visible-light photocatalytic activity, Chem. Eng. J., 2014, 246(16), 277-286. 